\title{
Gene Expressions for Signal Transduction under Acidic Conditions
}

\author{
Toshihiko Fukamachi ${ }^{1}$, Syunsuke Ikeda ${ }^{1}$, Xin Wang ${ }^{1}$, Hiromi Saito ${ }^{1}$, Masatoshi Tagawa ${ }^{2}$ and \\ Hiroshi Kobayashi, ${ }^{1, *}$
}

1 Graduate School of Pharmaceutical Sciences, Chiba University, 1-8-1, Inohana, Chuo-ku, Chiba 260-8675, Japan; E-Mails: t.fukamachi2011@gmail.com (T.F.); seika-admin@p.chiba-u.ac.jp (S.I.); oukin@chiba-u.jp (X.W.); hiromi.saito@thu.ac.jp (H.S.)

2 Division of Pathology and Cell Therapy, Chiba Cancer Center Research Institute, 666-2, Nitona, Chuo-ku, Chiba 260-8717, Japan; E-Mail: mtagawa@chiba-cc.jp

* Author to whom correspondence should be addressed; E-Mail: hiroshi.k@mx6.ttcn.ne.jp.

Received: 10 January 2013; in revised form: 18 February 2013 / Accepted: 27 February 2013 / Published: 8 March 2013

\begin{abstract}
Although it is now well known that some diseased areas, such as cancer nests, inflammation loci, and infarction areas, are acidified, little is known about cellular signal transduction, gene expression, and cellular functions under acidic conditions. Our group showed that different signal proteins were activated under acidic conditions compared with those observed in a typical medium of around $\mathrm{pH} 7.4$ that has been used until now. Investigations of gene expression under acidic conditions may be crucial to our understanding of signal transduction in acidic diseased areas. In this study, we investigated gene expression in mesothelioma cells cultured at an acidic $\mathrm{pH}$ using a DNA microarray technique. After $24 \mathrm{~h}$ culture at $\mathrm{pH}$ 6.7, expressions of 379 genes were increased more than twofold compared with those in cells cultured at $\mathrm{pH}$ 7.5. Genes encoding receptors, signal proteins including transcription factors, and cytokines including growth factors numbered 35 , 32, and 17 among the 379 genes, respectively. Since the functions of 78 genes are unknown, it can be argued that cells may have other genes for signaling under acidic conditions. The expressions of 37 of the 379 genes were observed to increase after as little as $2 \mathrm{~h}$. After $24 \mathrm{~h}$ culture at $\mathrm{pH}$ 6.7, expressions of 412 genes were repressed more than twofold compared with those in cells cultured at $\mathrm{pH} 7.5$, and the 412 genes contained 35, 76, and 7 genes encoding receptors, signal proteins including transcription factors, and cytokines including growth factors, respectively. These results suggest that the signal pathways in acidic diseased areas are different, at least in part, from those examined with cells cultured at a $\mathrm{pH}$ of around 7.4.
\end{abstract}


Keywords: gene expression; acidic conditions; signal pathways; cancer cells

\section{Introduction}

In mammals, the $\mathrm{pH}$ values of blood and tissues are usually maintained in a narrow range around 7.4 [1]. In contrast, diseased areas, such as cancer nests, inflammatory loci, and infarction areas, have been found to be acidic. The extracellular $\mathrm{pH}$ in the central regions of tumors decreases below 6.7 in several tumors as a consequence of lactate accumulation derived from a lack of sufficient vascularization or an increase in tumor-specific glycolysis under aerobic conditions combined with impaired mitochondrial oxidative phosphorylation [1-3]. Extracellular $\mathrm{pH}$ may also drop to a value below 6 due to leaking of intracellular contents and the destruction of blood vessels resulting in hypoxic metabolism and related lactic acid production during inflammation against the infection of pathogens [4]. Similar acidic environments were also associated with other inflammation. The $\mathrm{pH}$ value of articular fluid in the rheumatoid human knee joint was around 6.6, compared to around 7.3 in normal knee joints [5]. Other studies also showed the acidification of synovial fluid in arthritis [6-8].

Although cell functions mediated by a large number of enzymes with $\mathrm{pH}$-dependent catalytic activity are strongly affected by the disruption of $\mathrm{pH}$ homeostasis, there have been only a few studies of signal transduction, gene expression, and cellular functions under acidic conditions. Studies of Escherichia coli have suggested that this bacterium has multiple systems for a single function and that different systems having optimum activities at different $\mathrm{pH}$ values function under different $\mathrm{pH}$ conditions $[9,10]$.

Our group previously found that different signal transduction pathways function under acidic environments [11,12], and that CTIB, an IאB- $\beta$ variant, acted as a critical factor at $\mathrm{pH} 6.3$ but not at $\mathrm{pH} 7.4[13,14]$. Our group also showed the elevated activation of $\mathrm{p} 38$ and ERK in human T cells cultured at acidic $\mathrm{pH}[12,15]$. In addition to these reports by our group, activation of the MAPK pathways and increased COX-2 protein expression were reported in acid exposed cells in Barrett's metaplasia [16]. Matrix metalloproteinase-9 (MMP-9) expression was induced at acidic extracellular $\mathrm{pH}$ in mouse metastatic melanoma cells through phospholipase D-mitogen-activated protein kinase signaling [17]. Carbonic anhydrase 9 (CA9) expression was increased by acidosis via a hypoxia-independent mechanism that operates through modulation of the basic CA9 transcriptional machinery [18]. The gene expression of VEGF was stimulated at low extracellular $\mathrm{pH}[19,20]$. Glioma stem cells grown in low $\mathrm{pH}$ conditions displayed an increase in expressions of Olig2, Oct4, Nanog, interleukin-8 (IL-8), TIMP1, TIMP2, VEGF, Glut1, SerpinB9, and HIF2 $\alpha$, whereas expressions of Sox2, GFAP, and HIF1 $\alpha$ were repressed in the cells [21]. The expression of HIF1 $\alpha$ induced by hypoxia was decreased by acidosis and the expression of ATF4 was increased by the combination of acidosis with hypoxia [22].

These previous findings led us to assume that different signal pathways operate under acidic conditions in mammalian cells. In addition to the molecules reported in previous studies described above, numerous molecules may work preferentially under low $\mathrm{pH}$ conditions. To exhaustively identify genes working for cell proliferation under acidic conditions, we used cancer cells that were able to proliferate rapidly and investigated the gene expression in mesothelioma cells cultured at acidic $\mathrm{pH}$ using a DNA microarray technique in the present study. After $24 \mathrm{~h}$ culture at $\mathrm{pH} 6.7$, expressions of 379 
genes were increased more than twofold compared with those in cells cultured at $\mathrm{pH} 7.5$. The 379 genes contained 84 genes encoding receptors, signal proteins, transcription factors, cytokines, and growth factors, suggesting that the signal pathways in acidic diseased areas are different, at least in part, from those examined with cells cultured at $\mathrm{pH}$ around 7.4. The identified genes may be potential candidates for cancer chemotherapeutics. After $24 \mathrm{~h}$ culture at $\mathrm{pH}$ 6.7, expressions of 412 genes were repressed more than twofold compared with those in cells cultured at $\mathrm{pH} 7.5$, and genes encoding receptors, signal proteins, transcription factors, cytokines, and growth factors numbered 118 among the 412 genes.

\section{Materials and Methods}

\subsection{Cells and Medium for Their Maintenance}

Human mesothelial cell line H2052, human colon adenocarcinoma grade II cell line HT-29, human esophageal cancer cell line TE-11, human pancreatic ductal adenocarcinoma cell line BxPC3, and human hepatocellular carcinoma cell line HepG2 were used. For cell maintenance, cells were cultured in RPMI-1640 (WAKO) containing $10 \mu \mathrm{g} / \mathrm{mL}$ gentamicin (Sigma), $1 \mu \mathrm{g} / \mathrm{mL}$ fungizone (Bristol-Myers), and $10 \%$ FBS (Sigma) in the presence of $5 \% \mathrm{CO}_{2}$ at $37^{\circ} \mathrm{C}$.

\subsection{Cell Culture under Different $p H$ Conditions}

Media for cell culture at various $\mathrm{pH}$ values were prepared as follows. To minimize the $\mathrm{pH}$ change during the cell culture, $10 \mathrm{mM}$ PIPES [piperazine- $N, N^{\prime}$-bis(ethanesulfonic acid)] for acidic media or HEPES [4-(2-hydroxyethyl)piperazine-1-ethanesulfonic acid] for alkaline media was added to RPMI-1640 instead of $\mathrm{NaHCO}_{3}$. Medium containing fetal bovine serum (FBS) was often contaminated with germs when the medium $\mathrm{pH}$ was adjusted, and it was hard to sterilize medium containing FBS. Therefore, medium $\mathrm{pH}$ was first adjusted by the addition of $\mathrm{NaOH}$ to 6.3 and 7.6 before the addition of FBS. After sterilization of the medium by filtration, FBS was added. The medium $\mathrm{pH}$ values were changed into 6.7 and 7.5 by the addition of FBS, respectively. Cells were cultured at $37{ }^{\circ} \mathrm{C}$ without a $\mathrm{CO}_{2}$ supply but with an air supply to avoid hypoxia and constant humidity.

\subsection{DNA Microarray}

After H2052 cells had been cultured in pH 7.5 medium as described above for $24 \mathrm{~h}$ at $37{ }^{\circ} \mathrm{C}$, the medium was exchanged for $\mathrm{pH} 6.7$ medium, and cells were cultured at $37{ }^{\circ} \mathrm{C}$ for 2,5 , and $24 \mathrm{~h}$. Total RNA was isolated with the use of a TRI reagent (Sigma) according to the manufacturer's instructions, and microarray analysis was entrusted to Roche Diagnostics Corporation using the Roche NimbleGen Microarray A4487001-00-01. In order to compare, data were processed using the NimbleScan software that was developed based on previous papers [23,24].

\subsection{Real-Time Quantitative Polymerase Chain Reaction (PCR)}

Total RNA $(1 \mu \mathrm{g})$ prepared as described above was reverse-transcribed using ReverTra Ace (TOYOBO) in a total volume of $20 \mu \mathrm{L}$ containing the random primer for $18 \mathrm{~S}$ rRNA or the polyT primer for targeted genes. Real-time quantitative PCR amplification was performed with an ABI Prism 7000 
Sequence Detection System (Applied Biosystems) using the FastStart Universal SYBR Green Master[Rox] (Roche Diagnostics) according to the manufacturer's instructions. The PCR reaction was carried out with a mixture containing $12.5 \mu \mathrm{L}$ of Real-Time PCR Master Mix, 7.5 $\mu \mathrm{M}$ of each sense and antisense primer, $25 \mathrm{ng}$ of cDNA, and nuclease-free water in a total volume of $25 \mu \mathrm{L}$. The standard thermal profile for PCR amplification was $50{ }^{\circ} \mathrm{C}$ for $2 \mathrm{~min}, 95^{\circ} \mathrm{C}$ for $10 \mathrm{~min}$, and 40 cycles of $95^{\circ} \mathrm{C}$ for $15 \mathrm{~s}$ and $60^{\circ} \mathrm{C}$ for $60 \mathrm{~s}$. The primers used are shown in Table 1.

It has been reported that the content of ribosomes per cell is approximately $4 \times 10^{6}$ [25], and the amount of mRNA per cell can be estimated using $18 \mathrm{~S}$ rRNA as a control RNA with the following equation.

$$
4 \times 10^{6} \times 2^{\{(\mathrm{Ct} \text { of } 18 \mathrm{~S} \text { rRNA })-(\mathrm{Ct} \text { of sample RNA })\}}
$$

where $\mathrm{Ct}$ is the threshold cycle number.

Table 1. Primers used in this study.

\begin{tabular}{lll}
\hline Gene name & & \multicolumn{1}{c}{ Sequence } \\
\hline 18S rRNA & F; & TAGAGTGTTCAAAGCAGGCCC \\
& R; & CCAACAAATAGAACCGCGGT \\
IL-32 & F; & TCAAAGAGGGCTACCTGGAG \\
& R; & TTTCAAGTAGAGGAGTGAGCTCTG \\
ATP6V0D2 & F; & GACCCAGCAAGACTATATCAACC \\
& R; & TGGAGATGAATTTTCAGGTCTTC \\
TNFRSF9 & F; & AAACGGGGCAGAAAGAAACT \\
& R; & CTTCTGGAAATCGGCAGCTA \\
AREG & F; & GGGAGTGAGATTTCCCTGT \\
& $\mathrm{R} ;$ & AGCCAGGTATTTGTGGTCG \\
DMGDH & $\mathrm{F} ;$ & GAGCTCACGGCTGGATCTAC \\
& $\mathrm{R} ;$ & CCACCACCTGACCAGTTTCT \\
ERBB3 & $\mathrm{F} ;$ & TGCAGTGGATTCGAGAAGTG \\
& $\mathrm{R} ;$ & GGCAAACTTCCCATCGTAGA \\
\hline
\end{tabular}

18S rRNA, 18S ribosomal ribonucleic acid; IL-32, interleukin 32; ATP6V0D2, V0 subunit d2 of lysosomal $\mathrm{H}^{+}$ transporting ATPase; TNFRSF9, tumor necrosis factor receptor superfamily member 9; AREG, amphiregulin; DMGDH, dimethylglycine dehydrogenase; ERBB3, erythroblastic leukemia viral oncogene homolog 3.

\subsection{Other Reagents}

Taq DNA polymerase (Bio Academia) and Ribonuclease inhibitor (TOYOBO) were used.

\subsection{Statistical Analysis}

The Student's t-test was utilized in this study.

\section{Results}

\subsection{Highly Expressed Genes under Acidic Conditions in Mesothelioma Cells}

Approximately 24,000 genes were examined by microarray in mesothelioma cells (supplementary table), and the expressions of 379 genes were elevated more than twofold in cells cultured at $\mathrm{pH} 6.7$ for 
$24 \mathrm{~h}$ compared with the cells cultured at $\mathrm{pH} 7.5$ (Table 2). The accuracy of microarray analysis is mainly dependent on the RNA preparation. When the copy number of mRNA was low, the standard deviations of real-time quantitative PCR were close to 50\% (Figure 1). We therefore assumed that more than twofold changes were significant in the present study. The 379 genes contained 35, 32, and 17 genes encoding receptors, signal proteins including transcription factors, and cytokines including growth factors, respectively (Table 2). The functions of 78 genes among the 379 genes are unknown.

Table 2. Genes whose expression was induced more than twofold after 2, 5, and $24 \mathrm{~h}$ culture at acidic $\mathrm{pH}$.

\begin{tabular}{cccc}
\hline Gene & $\mathbf{2} \mathbf{~ h}$ & $\mathbf{5} \mathbf{h}$ & $\mathbf{2 4} \mathbf{~ h}$ \\
\hline number of genes & 260 & 175 & 379 \\
receptors & 29 & 22 & 35 \\
signal proteins $^{1}$ & 25 & 21 & 32 \\
cytokines $^{2}$ & 5 & 10 & 17 \\
\hline
\end{tabular}

${ }^{1}$ including transcription factors; ${ }^{2}$ including growth factors.

Figure 1. Gene expressions of IL-32, TNFRSF9, AREG, ERBB3, ATP6V0D2, and DMGDH at $\mathrm{pH} 7.5$ and 6.7 in TE-11 cells. TE-11 cells were incubated at $\mathrm{pH} 7.5$ (open bars) and 6.7 (closed bars) for $24 \mathrm{~h}$. mRNA number per one cell was detected with real-time quantitative PCR. Calculation is described in Materials and Methods. The mean values and standard deviations obtained from three independent experiments are represented. $\mathrm{P}$ values were calculated as described in Materials and Methods.
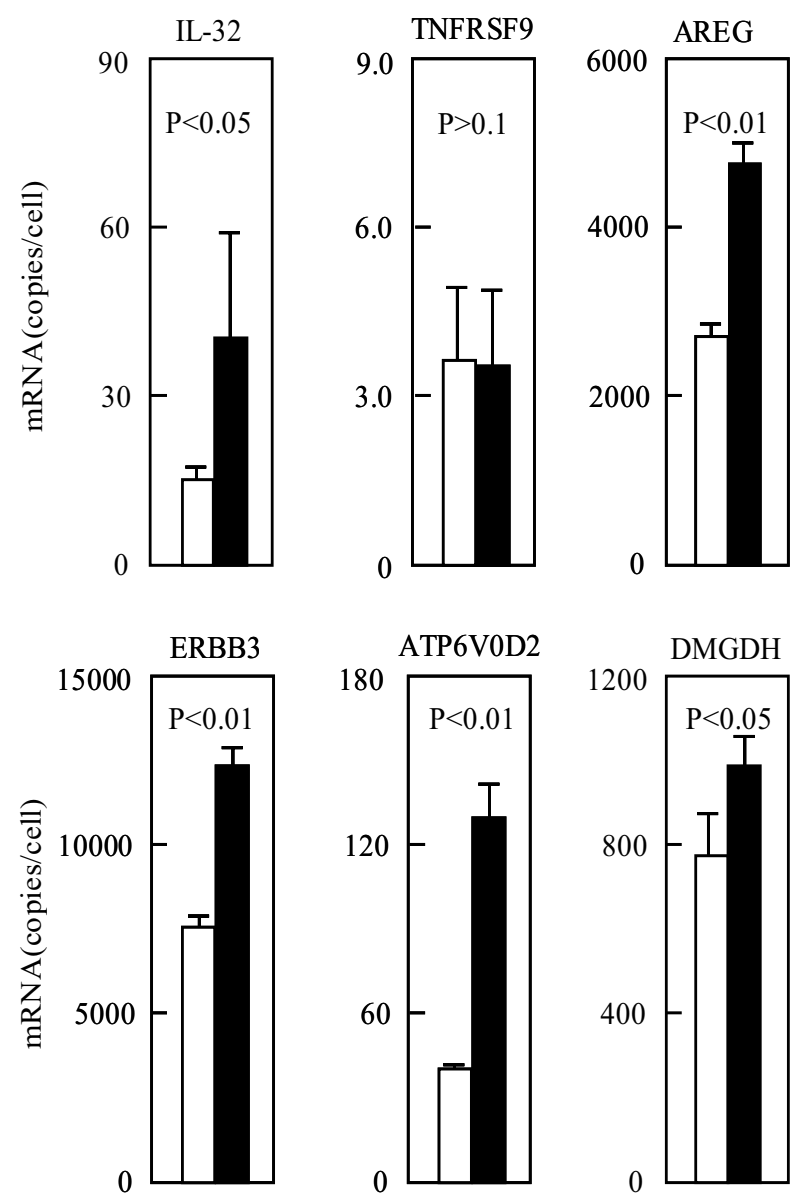
The expressions of IL-8 [21], MMP-9 [17], VEGF [19-21], CA9 [18], and COX-2 [16] were reported to increase under acidic stress. Our present results showed that the ratios of the expressions of IL-8, MMP-9, and VEGF in cells cultured at $\mathrm{pH} 6.7$ to those at $\mathrm{pH} 7.5$ were $2.52,1.90$, and 1.12, respectively. The expression of CA9 increased 1.35-fold at $\mathrm{pH}$ 6.7, but COX-2 expression was decreased at $\mathrm{pH}$ 6.7. It was reported that MnSOD participates in metastasis [26], and our data showed that the increase in the expression of MnSOD at acidic $\mathrm{pH}$ was 1.70 -fold.

The previous reports by our group showed that p38 and ERK were activated more strongly at acidic $\mathrm{pH}$ than at alkaline $\mathrm{pH}[12,15]$. The present data showed that $\mathrm{p} 38-\alpha$ (MAPK14) expression increased 1.71-fold after $5 \mathrm{~h}$ culture at $\mathrm{pH}$ 6.7, but decreased after $24 \mathrm{~h}$ culture at $\mathrm{pH} 6.7$ (supplementary table), suggesting that $\mathrm{p} 38-\alpha$ is up-regulated for a short time after cells have been stressed by acidosis. The expressions of $\mathrm{p} 38-\gamma$ (MAPK12) and ERK1 increased only 1.29-fold at $\mathrm{pH}$ 6.7. The expressions of other p38 and ERK families decreased slightly at acidic pH.

\subsection{Gene Expression after Culture for a Short Period at pH 6.7}

The gene expressions were also examined after 2 and $5 \mathrm{~h}$ at $\mathrm{pH}$ 6.7, and genes whose expression was increased were classified into seven groups as shown in Table 3 . The expressions of 260 genes increased more than twofold in cells cultured at $\mathrm{pH} 6.7$ for $2 \mathrm{~h}$ compared with $\mathrm{pH} 7.5$. The 260 genes contained 29, 25 , and 5 genes encoding receptors, signal proteins including transcription factors, and cytokines including growth factors, respectively (Table 2). The expressions of 15 among the 260 genes maintained high levels more than twofold for $24 \mathrm{~h}$ (Table 3, group A), while the expressions of 223 among the 260 genes decreased again after $24 \mathrm{~h}$ (Table 3, groups $\mathrm{E}$ and $\mathrm{G}$ ). The 191 genes were expressed at a high level

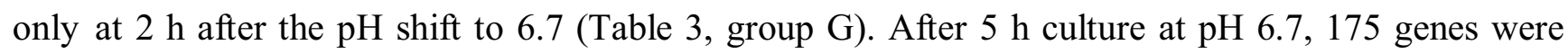
expressed more than twofold higher than the expression levels at $\mathrm{pH} 7.5$ (Table 2), and the 91 genes were expressed at a high level only at $5 \mathrm{~h}$ after acidic stress (Table 3, group F). Genes encoding proteins for signal pathways among the genes whose expression was increased at acidic $\mathrm{pH}$ are listed in Table 4.

Table 3. Classification of genes whose expression was induced at acidic $\mathrm{pH}$.

\begin{tabular}{|c|c|c|c|c|c|}
\hline \multirow{2}{*}{ Group } & \multicolumn{3}{|c|}{ Expression level * } & \multicolumn{2}{|c|}{ Number of genes } \\
\hline & $2 \mathrm{~h}$ & $5 \mathrm{~h}$ & $24 \mathrm{~h}$ & Total & Signal ** \\
\hline A & $>2$ & $>2$ & $>2$ & 15 & 7 \\
\hline $\mathrm{B}$ & $>2$ & $<=2$ & $>2$ & 22 & 3 \\
\hline $\mathrm{C}$ & $<=2$ & $>2$ & $>2$ & 37 & 8 \\
\hline $\mathrm{D}$ & $<=2$ & $<=2$ & $>2$ & 305 & 66 \\
\hline $\mathrm{E}$ & $>2$ & $>2$ & $<=2$ & 32 & 6 \\
\hline $\mathrm{F}$ & $<=2$ & $>2$ & $<=2$ & 91 & 32 \\
\hline \multirow[t]{2}{*}{ G } & $>2$ & $<=2$ & $<=2$ & 191 & 43 \\
\hline & & & total & 693 & 165 \\
\hline
\end{tabular}

* ratio of the expression in cells cultured at $\mathrm{pH} 6.7$ to those at $\mathrm{pH} 7.5$; ** genes encoding receptors, signal proteins, transcription factors, cytokines, and growth factors. 
Table 4. Genes encoding receptors, signal proteins, transcription factors, cytokines, and growth factors whose expression was high at $\mathrm{pH} 6.7$.

\begin{tabular}{|c|c|c|c|}
\hline Gene & Ratio * & Accession number & Description \\
\hline \multicolumn{4}{|l|}{ Group A } \\
\hline RSPO3 & 7.346 & NM_032784 & R-spondin 3 homolog (Xenopus laevis) \\
\hline IL32 & 3.711 & NM_001012631 & interleukin 32 \\
\hline TAS2R39 & 3.035 & NM_176881 & taste receptor, type 2, member 39 \\
\hline SLAMF8 & 2.751 & NM_020125 & SLAM family member 8 \\
\hline TRAF1 & 2.644 & NM_005658 & TNF receptor-associated factor 1 \\
\hline IL8 & 2.519 & NM_000584 & interleukin 8 \\
\hline RAB33A & 2.356 & NM_004794 & RAB33A, member RAS oncogene family \\
\hline \multicolumn{4}{|l|}{ Group B } \\
\hline LOC553158 & 4.306 & NM_181334 & PRR5-ARHGAP8 fusion \\
\hline PPP1R3E & 3.702 & XM_927029 & protein phosphatase 1 , regulatory (inhibitor) subunit $3 \mathrm{E}$ \\
\hline BDKRB2 & 2.168 & NM_000623 & bradykinin receptor $\mathrm{B} 2$ \\
\hline \multicolumn{4}{|l|}{ Group C } \\
\hline TNFRSF9 & 5.464 & NM_001561 & tumor necrosis factor receptor superfamily, member 9 \\
\hline FGF7 & 3.219 & NM_002009 & fibroblast growth factor 7 (keratinocyte growth factor) \\
\hline ZNF226 & 2.926 & NM_015919 & zinc finger protein 226 \\
\hline MGC17330 & 2.755 & NM_052880 & HGFL gene \\
\hline IL1RAP & 2.551 & NM_134470 & interleukin 1 receptor accessory protein \\
\hline NFKBIZ & 2.159 & NM_001005474 & $\begin{array}{l}\text { nuclear factor of } \kappa \text { light polypeptide gene enhancer in B-cells } \\
\text { inhibitor, } \zeta\end{array}$ \\
\hline OLR1 & 2.054 & NM_002543 & oxidized low density lipoprotein (lectin-like) receptor 1 \\
\hline TRIB3 & 2.031 & NM_021158 & tribbles homolog 3 (Drosophila) \\
\hline \multicolumn{4}{|l|}{ Group D } \\
\hline ERBB3 & 5.997 & NM_001982 & v-erb-b2 erythroblastic leukemia viral oncogene homolog 3 (avian) \\
\hline AREG & 5.650 & NM_001657 & amphiregulin (schwannoma-derived growth factor) \\
\hline LOC653193 & 4.485 & XM_926448 & $\begin{array}{l}\text { similar to Amphiregulin precursor (AR) (Colorectum cell-derived } \\
\text { growth factor) (CRDGF) }\end{array}$ \\
\hline RARRES1 & 3.882 & NM_002888 & retinoic acid receptor responder (tazarotene induced) 1 \\
\hline RRAD & 3.827 & NM_004165 & Ras-related associated with diabetes \\
\hline CRELD1 & 3.707 & NM_001031717 & cysteine-rich with EGF-like domains 1 \\
\hline ARHGAP8 & 3.547 & NM_001017526 & Rho GTPase activating protein 8 \\
\hline GPR78 & 3.302 & NM_080819 & G protein-coupled receptor 78 \\
\hline GDF15 & 3.112 & NM_004864 & growth differentiation factor 15 \\
\hline PTP4A3 & 3.037 & NM_007079 & protein tyrosine phosphatase type IVA, member 3 \\
\hline IL16 & 2.926 & NM_004513 & interleukin 16 (lymphocyte chemoattractant factor) \\
\hline PAQR6 & 2.919 & NM_198406 & progestin and adipoQ receptor family member VI \\
\hline OR52N4 & 2.915 & NM_001005175 & olfactory receptor, family 52 , subfamily $\mathrm{N}$, member 4 \\
\hline OR56B1 & 2.913 & NM_001005180 & olfactory receptor, family 56 , subfamily $\mathrm{B}$, member 1 \\
\hline PTPRQ & 2.834 & XM_926134 & protein tyrosine phosphatase, receptor type, $\mathrm{Q}$ \\
\hline LOC439957 & 2.784 & XM_495805 & similar to Ig $\kappa$ chain V-I region Walker precursor \\
\hline TNFSF9 & 2.744 & NM_003811 & tumor necrosis factor (ligand) superfamily, member 9 \\
\hline TNFSF7 & 2.714 & NM_001252 & tumor necrosis factor (ligand) superfamily, member 7 \\
\hline GPR87 & 2.641 & NM_023915 & G protein-coupled receptor 87 \\
\hline
\end{tabular}


Table 4. Cont.

\begin{tabular}{|c|c|c|c|}
\hline Gene & Ratio * & Accession number & Description \\
\hline \multicolumn{4}{|l|}{ Group D } \\
\hline GTF2IRD2B & 2.609 & NM_001003795 & general transcription factor 21 repeat domain containing $2 \beta$ \\
\hline RGS7 & 2.573 & NM_002924 & regulator of G-protein signalling 7 \\
\hline FOLR3 & 2.506 & NM_000804 & folate receptor $3(\gamma)$ \\
\hline RELB & 2.471 & NM_006509 & $\begin{array}{l}\text { v-rel reticuloendotheliosis viral oncogene homolog } \mathrm{B} \text {, nuclear } \\
\text { factor of } \kappa \text { light polypeptide gene enhancer in B-cells } 3 \text { (avian) }\end{array}$ \\
\hline TAS2R40 & 2.459 & NM_176882 & taste receptor, type 2, member 40 \\
\hline CCL3L3 & 2.418 & NM_001001437 & chemokine (C-C motif) ligand 3-like 3 \\
\hline GPR144 & 2.391 & NM_182611 & G protein-coupled receptor 144 \\
\hline RND1 & 2.389 & NM_014470 & Rho family GTPase 1 \\
\hline CD6 & 2.381 & NM_006725 & CD6 molecule \\
\hline ZNF165 & 2.368 & NM_003447 & zinc finger protein 165 \\
\hline ICHTHYIN & 2.353 & XM_371777 & ichthyin protein \\
\hline PKD1L1 & 2.334 & NM_138295 & polycystic kidney disease 1 like 1 \\
\hline NPHP1 & 2.318 & NM_207181 & nephronophthisis 1 (juvenile) \\
\hline PTK6 & 2.312 & NM_005975 & PTK6 protein tyrosine kinase 6 \\
\hline IL15RA & 2.282 & NM_002189 & interleukin 15 receptor, $\alpha$ \\
\hline POU6F1 & 2.271 & NM_002702 & POU domain, class 6 , transcription factor 1 \\
\hline TNFRSF10C & 2.268 & NM_003841 & $\begin{array}{l}\text { tumor necrosis factor receptor superfamily, member } 10 \mathrm{c} \text {, decoy } \\
\text { without an intracellular domain }\end{array}$ \\
\hline IL15 & 2.248 & NM_172175 & interleukin 15 \\
\hline P2RY12 & 2.233 & NM_176876 & purinergic receptor P2Y, G-protein coupled, 12 \\
\hline MST1 & 2.186 & NM_020998 & macrophage stimulating 1 (hepatocyte growth factor-like) \\
\hline KDR & 2.184 & NM_002253 & kinase insert domain receptor (a type III receptor tyrosine kinase) \\
\hline GPR68 & 2.174 & NM_003485 & G protein-coupled receptor 68 \\
\hline GPR44 & 2.170 & NM_004778 & G protein-coupled receptor 44 \\
\hline RAI17 & 2.162 & NM_020338 & retinoic acid induced 17 \\
\hline OR10V1 & 2.156 & NM_001005324 & olfactory receptor, family 10 , subfamily $\mathrm{V}$, member 1 \\
\hline ASB1 & 2.148 & NM_016114 & ankyrin repeat and SOCS box-containing 1 \\
\hline CMTM1 & 2.146 & NM_181293 & CKLF-like MARVEL transmembrane domain containing 1 \\
\hline PHF7 & 2.141 & NM_173341 & PHD finger protein 7 \\
\hline GPRC5D & 2.114 & NM_018654 & G protein-coupled receptor, family $\mathrm{C}$, group 5 , member $\mathrm{D}$ \\
\hline TP53INP2 & 2.108 & NM_021202 & tumor protein p53 inducible nuclear protein 2 \\
\hline ARHGAP15 & 2.082 & NM_018460 & Rho GTPase activating protein 15 \\
\hline GEFT & 2.066 & NM_182947 & $\mathrm{RAC} / \mathrm{CDC} 42$ exchange factor \\
\hline PIM1 & 2.062 & NM_002648 & pim-1 oncogene \\
\hline TNFRSF25 & 2.055 & NM_148973 & tumor necrosis factor receptor superfamily, member 25 \\
\hline GPR157 & 2.049 & NM_024980 & G protein-coupled receptor 157 \\
\hline NR2E3 & 2.045 & NM_014249 & nuclear receptor subfamily 2 , group E, member 3 \\
\hline LOC619207 & 2.042 & XM_927510 & scavenger receptor protein family member \\
\hline WISP3 & 2.033 & NM_003880 & WNT1 inducible signaling pathway protein 3 \\
\hline P2RX4 & 2.030 & NM_002560 & purinergic receptor $\mathrm{P} 2 \mathrm{X}$, ligand-gated ion channel, 4 \\
\hline RASD2 & 2.029 & NM_014310 & RASD family, member 2 \\
\hline FGF2 & 2.028 & NM_002006 & fibroblast growth factor 2 (basic) \\
\hline RGR & 2.011 & NM_001012720 & retinal G protein coupled receptor \\
\hline
\end{tabular}


Table 4. Cont.

\begin{tabular}{|c|c|c|c|}
\hline Gene & Ratio * & Accession number & Description \\
\hline \multicolumn{4}{|l|}{ Group D } \\
\hline NRXN2 & 2.011 & NM_015080 & neurexin 2 \\
\hline EDG4 & 2.009 & NM_004720 & $\begin{array}{l}\text { endothelial differentiation, lysophosphatidic acid G-protein-coupled } \\
\text { receptor, } 4\end{array}$ \\
\hline KGFLP1 & 2.006 & NM_174950 & keratinocyte growth factor-like protein 1 \\
\hline PTPRH & 2.005 & NM_002842 & protein tyrosine phosphatase, receptor type, $\mathrm{H}$ \\
\hline OR52A5 & 2.001 & NM_001005160 & olfactory receptor, family 52 , subfamily A, member 5 \\
\hline \multicolumn{4}{|l|}{ Group E } \\
\hline KLF9 & 3.169 & NM_001206 & Kruppel-like factor 9 \\
\hline CLASP2 & 2.029 & NM_015097 & cytoplasmic linker associated protein 2 \\
\hline E2F5 & 2.267 & NM_001951 & E2F transcription factor 5, p130-binding \\
\hline ZNF474 & 2.203 & NM_207317 & zinc finger protein 474 \\
\hline GPR37 & 2.411 & NM_005302 & G protein-coupled receptor 37 (endothelin receptor type B-like) \\
\hline PAX5 & 2.097 & NM_016734 & paired box gene 5 (B-cell lineage specific activator) \\
\hline \multicolumn{4}{|l|}{ Group F } \\
\hline OR4D6 & 2.809 & NM_001004708 & olfactory receptor, family 4 , subfamily $\mathrm{D}$, member 6 \\
\hline OR5B12 & 2.783 & NM_001004733 & olfactory receptor, family 5 , subfamily B, member 12 \\
\hline VENTX & 2.515 & NM_014468 & VENT homeobox homolog (Xenopus laevis) \\
\hline UNC5B & 2.438 & NM_170744 & unc-5 homolog B (C. elegans) \\
\hline OR1J4 & 2.416 & NM_001004452 & olfactory receptor, family 1 , subfamily J, member 4 \\
\hline NR5A1 & 2.338 & NM_004959 & nuclear receptor subfamily 5 , group A, member 1 \\
\hline SESN2 & 2.331 & NM_031459 & sestrin 2 \\
\hline CCL25 & 2.308 & NM_148888 & chemokine (C-C motif) ligand 25 \\
\hline IL21R & 2.301 & NM_021798 & interleukin 21 receptor \\
\hline ATF3 & 2.220 & NM_001030287 & activating transcription factor 3 \\
\hline TLR1 & 2.212 & NM_003263 & toll-like receptor 1 \\
\hline C1QTNF7 & 2.202 & NM_031911 & $\mathrm{C} 1 \mathrm{q}$ and tumor necrosis factor related protein 7 \\
\hline TBX19 & 2.186 & NM_005149 & T-box 19 \\
\hline MXD1 & 2.163 & NM_002357 & MAX dimerization protein 1 \\
\hline GTPBP2 & 2.148 & NM_019096 & GTP binding protein 2 \\
\hline NR4A2 & 2.117 & NM_006186 & nuclear receptor subfamily 4 , group A, member 2 \\
\hline PHLDA1 & 2.116 & NM_007350 & pleckstrin homology-like domain, family A, member 1 \\
\hline LCP1 & 2.111 & NM_002298 & lymphocyte cytosolic protein 1 (L-plastin) \\
\hline FGFBP1 & 2.111 & NM_005130 & fibroblast growth factor binding protein 1 \\
\hline OR2B11 & 2.078 & NM_001004492 & olfactory receptor, family 2 , subfamily B, member 11 \\
\hline OR56A3 & 2.073 & NM_001003443 & olfactory receptor, family 56 , subfamily A, member 3 \\
\hline GH2 & 2.071 & NM_002059 & growth hormone 2 \\
\hline PTHLH & 2.061 & NM_002820 & parathyroid hormone-like hormone \\
\hline THBD & 2.059 & NM_000361 & thrombomodulin \\
\hline HGF & 2.055 & NM_000601 & hepatocyte growth factor (hepapoietin A; scatter factor) \\
\hline ARTN & 2.051 & NM_003976 & $\operatorname{artemin}$ \\
\hline EPHA8 & 2.040 & NM_020526 & EPH receptor A8 \\
\hline CD200R1 & 2.023 & NM_138939 & CD200 receptor 1 \\
\hline FZD7 & 2.017 & NM_003507 & frizzled homolog 7 (Drosophila) \\
\hline S100A12 & 2.012 & NM_005621 & S100 calcium binding protein A12 (calgranulin C) \\
\hline
\end{tabular}


Table 4. Cont.

\begin{tabular}{|c|c|c|c|}
\hline Gene & Ratio * & Accession number & Description \\
\hline \multicolumn{4}{|l|}{ Group F } \\
\hline SPIC & 2.008 & NM_152323 & Spi-C transcription factor (Spi-1/PU.1 related) \\
\hline VSIG4 & 2.006 & NM_007268 & V-set and immunoglobulin domain containing 4 \\
\hline \multicolumn{4}{|l|}{ Group G } \\
\hline TCF21 & 3.518 & NM_198392 & transcription factor 21 \\
\hline DOK6 & 2.827 & NM_152721 & docking protein 6 \\
\hline FZD3 & 2.815 & NM_017412 & frizzled homolog 3 (Drosophila) \\
\hline CD86 & 2.686 & NM_006889 & CD86 molecule \\
\hline OR2L13 & 2.677 & NM_175911 & olfactory receptor, family 2 , subfamily L, member 13 \\
\hline IL18RAP & 2.557 & NM_003853 & interleukin 18 receptor accessory protein \\
\hline TRPA1 & 2.427 & NM_007332 & transient receptor potential cation channel, subfamily A, member 1 \\
\hline RTP3 & 2.417 & NM_031440 & receptor transporter protein 3 \\
\hline GRIA2 & 2.353 & NM_000826 & glutamate receptor, ionotropic, AMPA 2 \\
\hline OR51E1 & 2.351 & NM_152430 & olfactory receptor, family 51 , subfamily $\mathrm{E}$, member 1 \\
\hline GRM2 & 2.343 & NM_000839 & glutamate receptor, metabotropic 2 \\
\hline FCRLM1 & 2.335 & NM_032738 & Fc receptor-like and mucin-like 1 \\
\hline NR4A3 & 2.332 & NM_173199 & nuclear receptor subfamily 4 , group A, member 3 \\
\hline SPI1 & 2.288 & NM_003120 & spleen focus forming virus (SFFV) proviral integration oncogene spil \\
\hline SMAD6 & 2.282 & NM_005585 & SMAD, mothers against DPP homolog 6 (Drosophila) \\
\hline LOC642400 & 2.281 & XM_925921 & similar to tripartite motif protein 17 \\
\hline CAMTA1 & 2.274 & NM_015215 & calmodulin binding transcription activator 1 \\
\hline GDF6 & 2.260 & NM_001001557 & growth differentiation factor 6 \\
\hline OR51B2 & 2.258 & NM_033180 & olfactory receptor, family 51 , subfamily $\mathrm{B}$, member 2 \\
\hline OR7D4 & 2.238 & NM_001005191 & olfactory receptor, family 7 , subfamily D, member 4 \\
\hline ECGF1 & 2.227 & NM_001953 & endothelial cell growth factor 1 (platelet-derived) \\
\hline LAIR1 & 2.218 & NM_002287 & leukocyte-associated immunoglobulin-like receptor 1 \\
\hline NELL1 & 2.209 & NM_006157 & NEL-like 1 (chicken) \\
\hline OR8J1 & 2.188 & NM_001005205 & olfactory receptor, family 8 , subfamily $\mathrm{J}$, member 1 \\
\hline GRM3 & 2.178 & NM_000840 & glutamate receptor, metabotropic 3 \\
\hline PRKCQ & 2.170 & NM_006257 & protein kinase $\mathrm{C}, \theta$ \\
\hline PPP1R3F & 2.164 & NM_033215 & protein phosphatase 1 , regulatory (inhibitor) subunit $3 \mathrm{~F}$ \\
\hline LOC642338 & 2.150 & XM_925874 & similar to vomeronasal 1 receptor, $\mathrm{C} 3$ \\
\hline CPNE5 & 2.148 & NM_020939 & copine V \\
\hline EPHB6 & 2.134 & NM_004445 & EPH receptor B6 \\
\hline OR51M1 & 2.119 & NM_001004756 & olfactory receptor, family 51 , subfamily $\mathrm{M}$, member 1 \\
\hline PTPRC & 2.105 & NM_002838 & protein tyrosine phosphatase, receptor type, $\mathrm{C}$ \\
\hline EBF3 & 2.100 & NM_001005463 & early B-cell factor 3 \\
\hline BMPR1B & 2.091 & NM_001203 & bone morphogenetic protein receptor, type IB \\
\hline HRH4 & 2.084 & NM_021624 & histamine receptor $\mathrm{H} 4$ \\
\hline SHE & 2.082 & NM_001010846 & Src homology 2 domain containing $\mathrm{E}$ \\
\hline T2R55 & 2.073 & NM_181429 & taste receptor T2R55 \\
\hline SBK1 & 2.067 & NM_001024401 & SH3-binding domain kinase 1 \\
\hline RASGRP2 & 2.048 & NM_005825 & RAS guanyl releasing protein 2 (calcium and DAG-regulated) \\
\hline CD96 & 2.047 & NM_005816 & CD96 molecule \\
\hline GRIN2B & 2.028 & NM_000834 & glutamate receptor, ionotropic, $N$-methyl D-aspartate 2B \\
\hline
\end{tabular}


Table 4. Cont.

\begin{tabular}{llll}
\hline Gene & Ratio $*$ & Accession number & Description \\
\hline Group G & & & \\
YAF2 & 2.018 & NM_001012424 & YY1 associated factor 2 \\
LCP2 & 2.001 & NM_005565 & $\begin{array}{l}\text { lymphocyte cytosolic protein 2 (SH2 domain containing leukocyte } \\
\end{array}$ \\
& & protein of 76 kDa) \\
\hline
\end{tabular}

* ratio of the expression in cells cultured at $\mathrm{pH} 6.7$ after 24,5 , and $2 \mathrm{~h}$ culture to those at $\mathrm{pH} 7.5$ in groups A to $\mathrm{D}, \mathrm{E}$ to $\mathrm{F}$, and $\mathrm{G}$, respectively.

\subsection{Genes Whose Expression Was Repressed at Acidic pH}

The expressions of 412 genes were repressed more than twofold in cells cultured at $\mathrm{pH} 6.7$ for $24 \mathrm{~h}$, and the 412 genes contained 35, 76, and 7 genes encoding receptors, signal proteins including transcription factors, and cytokines including growth factors, respectively (Table 5). Genes whose expression was repressed at acidic pH were classified into seven groups, as shown in Table 6 . The expressions of 17 genes decreased already after $2 \mathrm{~h}$ culture at $\mathrm{pH} 6.7$ (Table 6, groups A and B).

The expressions of 385 genes were repressed more than twofold in cells cultured at $\mathrm{pH} 6.7$ for $2 \mathrm{~h}$ (Table 5), but the expressions of 368 of these 385 genes increased again after $24 \mathrm{~h}$ culture (Table 6, groups $\mathrm{E}$ and $\mathrm{G})$. The expressions of 343 among 385 genes were repressed only after $2 \mathrm{~h}$ culture at $\mathrm{pH}$ 6.7 (Table 6, group G). After $5 \mathrm{~h}$ culture at $\mathrm{pH}$ 6.7, the expressions of 141 genes were repressed (Table 5) and 76 genes were repressed only after 5 h culture at pH 6.7 (Table 6, group F). Genes encoding proteins for signal pathways among the genes whose expression was repressed at acidic $\mathrm{pH}$ are listed in Table 7.

Table 5. Genes whose expression was repressed more than twofold after 2, 5, and $24 \mathrm{~h}$ culture at acidic $\mathrm{pH}$.

\begin{tabular}{lrrr}
\hline Gene & $\mathbf{2 ~ h}$ & $\mathbf{5 ~ h}$ & $\mathbf{2 4} \mathbf{~ h}$ \\
\hline number of genes & 385 & 141 & 412 \\
receptors & 32 & 14 & 35 \\
signal proteins ${ }^{1}$ & 31 & 14 & 76 \\
cytokines $^{2}$ & 8 & 0 & 7 \\
\hline \multicolumn{2}{c}{${ }^{1}$ including transcription factors; ${ }^{2}$ including growth factors. }
\end{tabular}

Table 6. Classification of genes whose expression was repressed at acidic $\mathrm{pH}$.

\begin{tabular}{crrrrrrr}
\hline \multirow{2}{*}{ Group } & \multicolumn{3}{c}{ Expression level * } & & \multicolumn{2}{c}{ Number of genes } \\
\cline { 2 - 3 } \cline { 6 - 7 } & $\mathbf{2 ~ h}$ & $\mathbf{5 ~ h}$ & $\mathbf{2 4} \mathbf{~ h}$ & & Total & Signal ** \\
\hline $\mathrm{A}$ & $<0.5$ & $<0.5$ & $<0.5$ & & 8 & 4 \\
$\mathrm{~B}$ & $<0.5$ & $>=0.5$ & $<0.5$ & & 9 & 3 \\
$\mathrm{C}$ & $>=0.5$ & $<0.5$ & $<0.5$ & & 32 & 4 \\
$\mathrm{D}$ & $>=0.5$ & $>=0.5$ & $<0.5$ & & 363 & 107 \\
$\mathrm{E}$ & $<0.5$ & $<0.5$ & $>=0.5$ & & 25 & 8 \\
$\mathrm{~F}$ & $>=0.5$ & $<0.5$ & $>=0.5$ & & 76 & 12 \\
$\mathrm{G}$ & $<0.5$ & $>=0.5$ & $>=0.5$ & & 343 & 56 \\
\hline
\end{tabular}

* ratio of the expression in cells cultured at $\mathrm{pH} 6.7$ to those at $\mathrm{pH} 7.5$; ** genes encoding receptors, signal proteins, transcription factors, cytokines, and growth factors. 
Table 7. Genes encoding receptors, signal proteins, transcription factors, cytokines, and growth factors whose expression was repressed at $\mathrm{pH}$ 6.7.

\begin{tabular}{|c|c|c|c|}
\hline Gene & Ratio * & Accession number & Description \\
\hline \multicolumn{4}{|l|}{ Group A } \\
\hline IL11 & 0.158 & NM_000641 & interleukin 11 \\
\hline CCRL2 & 0.324 & NM_003965 & chemokine (C-C motif) receptor-like 2 \\
\hline CD300LG & 0.444 & NM_145273 & CD300 molecule-like family member $g$ \\
\hline ATOH1 & 0.459 & NM_005172 & atonal homolog 1 (Drosophila) \\
\hline \multicolumn{4}{|l|}{ Group B } \\
\hline RASGEF1C & 0.486 & NM_001031799 & RasGEF domain family, member $1 \mathrm{C}$ \\
\hline LGR5 & 0.491 & NM_003667 & leucine-rich repeat-containing $\mathrm{G}$ protein-coupled receptor 5 \\
\hline HSH2D & 0.493 & NM_032855 & hematopoietic $\mathrm{SH} 2$ domain containing \\
\hline \multicolumn{4}{|l|}{ Group C } \\
\hline TLR4 & 0.099 & NM_138554 & toll-like receptor 4 \\
\hline TSSK2 & 0.421 & NM_053006 & testis-specific serine kinase 2 \\
\hline ADRB2 & 0.475 & NM_000024 & adrenergic, $\beta-2-$, receptor, surface \\
\hline FLRT2 & 0.400 & NM_013231 & fibronectin leucine rich transmembrane protein 2 \\
\hline \multicolumn{4}{|l|}{ Group D } \\
\hline $\mathrm{E} 2 \mathrm{~F} 2$ & 0.150 & NM_004091 & E2F transcription factor 2 \\
\hline ADRA2A & 0.193 & NM_000681 & adrenergic, $\alpha-2 \mathrm{~A}-$, receptor \\
\hline APLN & 0.243 & NM_017413 & apelin, AGTRL1 ligand \\
\hline REEP1 & 0.244 & NM_022912 & receptor accessory protein 1 \\
\hline ARHGAP26 & 0.252 & NM_015071 & Rho GTPase activating protein 26 \\
\hline UHRF1 & 0.259 & NM_013282 & ubiquitin-like, containing PHD and RING finger domains, 1 \\
\hline ZNF367 & 0.261 & NM_153695 & zinc finger protein 367 \\
\hline POU5F1 & 0.267 & NM_203289 & POU domain, class 5 , transcription factor 1 \\
\hline RGS4 & 0.269 & NM_005613 & regulator of G-protein signalling 4 \\
\hline RHOJ & 0.269 & NM_020663 & ras homolog gene family, member $\mathrm{J}$ \\
\hline MCF2 & 0.270 & NM_005369 & MCF. 2 cell line derived transforming sequence \\
\hline CHRNA5 & 0.276 & NM_000745 & cholinergic receptor, nicotinic, $\alpha 5$ \\
\hline GPR115 & 0.285 & NM_153838 & G protein-coupled receptor 115 \\
\hline SORCS3 & 0.286 & NM_014978 & sortilin-related VPS10 domain containing receptor 3 \\
\hline RBM14 & 0.287 & NM_006328 & RNA binding motif protein 14 \\
\hline PDE4B & 0.298 & NM_001037339 & $\begin{array}{l}\text { phosphodiesterase } 4 \mathrm{~B} \text {, cAMP-specific (phosphodiesterase E4 dunce homolog, } \\
\text { Drosophila) }\end{array}$ \\
\hline PIK3CG & 0.310 & NM_002649 & phosphoinositide-3-kinase, catalytic, $\gamma$ polypeptide \\
\hline RGPD2 & 0.311 & NM_001024457 & RANBP2-like and GRIP domain containing 2 \\
\hline TP53RK & 0.314 & NM_033550 & TP53 regulating kinase \\
\hline MAP2K6 & 0.320 & NM_002758 & mitogen-activated protein kinase kinase 6 \\
\hline TP73 & 0.330 & NM_005427 & tumor protein $\mathrm{p} 73$ \\
\hline GPR63 & 0.338 & NM_030784 & G protein-coupled receptor 63 \\
\hline FST & 0.340 & NM_006350 & follistatin \\
\hline MPP4 & 0.347 & NM_033066 & membrane protein, palmitoylated 4 (MAGUK p55 subfamily member 4) \\
\hline PDE4D & 0.350 & NM_006203 & $\begin{array}{l}\text { phosphodiesterase 4D, cAMP-specific (phosphodiesterase E3 dunce homolog, } \\
\text { Drosophila) }\end{array}$ \\
\hline ANXA10 & 0.355 & NM_007193 & annexin $\mathrm{A} 10$ \\
\hline
\end{tabular}


Table 7. Cont.

\begin{tabular}{|c|c|c|c|}
\hline Gene & Ratio * & Accession number & Description \\
\hline \multicolumn{4}{|l|}{ Group D } \\
\hline RBL1 & 0.355 & NM_002895 & retinoblastoma-like 1 (p107) \\
\hline KIT & 0.360 & NM_000222 & v-kit Hardy-Zuckerman 4 feline sarcoma viral oncogene homolog \\
\hline PBX1 & 0.368 & NM_002585 & pre-B-cell leukemia transcription factor 1 \\
\hline MTUS1 & 0.371 & NM_001001924 & mitochondrial tumor suppressor 1 \\
\hline RORB & 0.386 & NM_006914 & RAR-related orphan receptor B \\
\hline LHX6 & 0.389 & NM_014368 & LIM homeobox 6 \\
\hline PAQR4 & 0.392 & NM_152341 & progestin and adipoQ receptor family member IV \\
\hline ABRA & 0.394 & NM_139166 & actin-binding Rho activating protein \\
\hline GDAP1 & 0.396 & NM_018972 & ganglioside-induced differentiation-associated protein 1 \\
\hline C1QTNF2 & 0.399 & NM_031908 & $\mathrm{C} 1 \mathrm{q}$ and tumor necrosis factor related protein 2 \\
\hline CMTM1 & 0.400 & NM_181289 & CKLF-like MARVEL transmembrane domain containing 1 \\
\hline MLR1 & 0.404 & NM_153686 & transcription factor MLR1 \\
\hline TSPAN8 & 0.405 & NM_004616 & tetraspanin 8 \\
\hline SH2D4B & 0.406 & NM_207372 & $\mathrm{SH} 2$ domain containing 4B \\
\hline E2F1 & 0.406 & NM_005225 & E2F transcription factor 1 \\
\hline VANGL1 & 0.411 & NM_138959 & vang-like 1 (van gogh, Drosophila) \\
\hline DUSP6 & 0.415 & NM_001946 & dual specificity phosphatase 6 \\
\hline FZD3 & 0.416 & NM_017412 & frizzled homolog 3 (Drosophila) \\
\hline PPARGC1A & 0.417 & NM_013261 & peroxisome proliferative activated receptor, $\gamma$, coactivator $1, \alpha$ \\
\hline HOXB7 & 0.419 & NM_004502 & homeobox B7 \\
\hline PTGER2 & 0.420 & NM_000956 & prostaglandin E receptor 2 (subtype $\mathrm{EP} 2$ ), $53 \mathrm{kDa}$ \\
\hline NGEF & 0.421 & NM_019850 & neuronal guanine nucleotide exchange factor \\
\hline FGF18 & 0.421 & NM_033649 & fibroblast growth factor 18 \\
\hline LOC653528 & 0.425 & XM_927910 & $\begin{array}{l}\text { similar to Teratocarcinoma-derived growth factor } 2 \text { (Epidermal growth } \\
\text { factor-like cripto protein CR3) (Cripto-3 growth factor) }\end{array}$ \\
\hline OR4N2 & 0.426 & NM_001004723 & olfactory receptor, family 4 , subfamily $\mathrm{N}$, member 2 \\
\hline NKX6-2 & 0.429 & NM_177400 & NK6 transcription factor related, locus 2 (Drosophila) \\
\hline NFKBIL2 & 0.431 & NM_013432 & nuclear factor of $\kappa$ light polypeptide gene enhancer in B-cells inhibitor-like 2 \\
\hline PTPN22 & 0.431 & NM_012411 & protein tyrosine phosphatase, non-receptor type 22 (lymphoid) \\
\hline LOC392269 & 0.432 & XM_928112 & similar to Transcription factor SOX-2 \\
\hline MAL2 & 0.432 & NM_052886 & mal, T-cell differentiation protein 2 \\
\hline SELPLG & 0.434 & NM_003006 & selectin P ligand \\
\hline GPR177 & 0.434 & NM_001002292 & G protein-coupled receptor 177 \\
\hline NCOA5 & 0.437 & NM_020967 & nuclear receptor coactivator 5 \\
\hline RIF1 & 0.437 & NM_018151 & RAP1 interacting factor homolog (yeast) \\
\hline GPR3 & 0.439 & NM_005281 & G protein-coupled receptor 3 \\
\hline CDC14A & 0.439 & NM_003672 & CDC14 cell division cycle 14 homolog A (S. cerevisiae) \\
\hline RP3-509I19.5 & 0.444 & XM_294019 & similar to ECT2 protein (Epithelial cell transforming sequence 2 oncogene) \\
\hline ADORA1 & 0.444 & NM_000674 & adenosine A1 receptor \\
\hline PTCH & 0.446 & NM_000264 & patched homolog (Drosophila) \\
\hline TCF21 & 0.446 & NM_003206 & transcription factor 21 \\
\hline SPRY4 & 0.448 & NM_030964 & sprouty homolog 4 (Drosophila) \\
\hline CBX2 & 0.450 & NM_005189 & chromobox homolog 2 (Pc class homolog, Drosophila) \\
\hline OR6C74 & 0.451 & NM_001005490 & olfactory receptor, family 6 , subfamily C, member 74 \\
\hline
\end{tabular}


Table 7. Cont.

\begin{tabular}{|c|c|c|c|}
\hline Gene & Ratio * & Accession number & Description \\
\hline \multicolumn{4}{|l|}{ Group D } \\
\hline CXCL14 & 0.452 & NM_004887 & chemokine (C-X-C motif) ligand 14 \\
\hline CUBN & 0.453 & NM_001081 & cubilin (intrinsic factor-cobalamin receptor) \\
\hline NRG2 & 0.457 & NM_013985 & neuregulin 2 \\
\hline SGIP1 & 0.457 & NM_032291 & SH3-domain GRB2-like (endophilin) interacting protein 1 \\
\hline GNGT2 & 0.457 & NM_031498 & guanine nucleotide binding protein ( $G$ protein), $\gamma$ transducing activity polypeptide 2 \\
\hline EBF & 0.458 & NM_024007 & early B-cell factor \\
\hline ACVR1C & 0.458 & NM_145259 & activin A receptor, type IC \\
\hline PHTF2 & 0.458 & NM_020432 & putative homeodomain transcription factor 2 \\
\hline RASSF1 & 0.460 & NM_007182 & Ras association (RalGDS/AF-6) domain family 1 \\
\hline GPR109A & 0.462 & NM_177551 & G protein-coupled receptor 109A \\
\hline TSHR & 0.463 & NM_000369 & thyroid stimulating hormone receptor \\
\hline SIM2 & 0.468 & NM_009586 & single-minded homolog 2 (Drosophila) \\
\hline GABRA6 & 0.469 & NM_000811 & $\gamma$-aminobutyric acid (GABA) A receptor, alpha 6 \\
\hline LAT2 & 0.469 & NM_032464 & linker for activation of $\mathrm{T}$ cells family, member 2 \\
\hline PHKG1 & 0.472 & NM_006213 & phosphorylase kinase, $\gamma 1$ (muscle) \\
\hline RGPD4 & 0.473 & XM_496581 & RANBP2-like and GRIP domain containing 4 \\
\hline NKD1 & 0.474 & NM_033119 & naked cuticle homolog 1 (Drosophila) \\
\hline ZNF588 & 0.475 & NM_001013746 & zinc finger protein 588 \\
\hline SH3TC2 & 0.476 & NM_024577 & SH3 domain and tetratricopeptide repeats 2 \\
\hline FZD1 & 0.478 & NM_003505 & frizzled homolog 1 (Drosophila) \\
\hline PKMYT1 & 0.478 & NM_004203 & protein kinase, membrane associated tyrosine/threonine 1 \\
\hline DUSP4 & 0.480 & NM_001394 & dual specificity phosphatase 4 \\
\hline WDR4 & 0.480 & NM_018669 & WD repeat domain 4 \\
\hline WDR76 & 0.481 & NM_024908 & WD repeat domain 76 \\
\hline WDHD1 & 0.483 & NM_001008396 & WD repeat and HMG-box DNA binding protein 1 \\
\hline HOXA7 & 0.485 & NM_006896 & homeobox A7 \\
\hline WDR69 & 0.486 & NM_178821 & WD repeat domain 69 \\
\hline TFAP2C & 0.487 & NM_003222 & transcription factor AP-2 $\gamma$ (activating enhancer binding protein $2 \gamma$ ) \\
\hline CDGAP & 0.488 & NM_020754 & Cdc42 GTPase-activating protein \\
\hline RPIB9 & 0.491 & NM_138290 & Rap2-binding protein 9 \\
\hline IFNAR1 & 0.493 & NM_000629 & interferon $(\alpha, \beta$ and $\omega)$ receptor 1 \\
\hline POU3F2 & 0.493 & NM_005604 & POU domain, class 3 , transcription factor 2 \\
\hline LOC402279 & 0.497 & XM_377945 & similar to glutamate receptor, metabotropic 8 \\
\hline EYA4 & 0.498 & NM_004100 & eyes absent homolog 4 (Drosophila) \\
\hline ISL1 & 0.498 & NM_002202 & ISL1 transcription factor, LIM/homeodomain, (islet-1) \\
\hline SIRPD & 0.499 & NM_178460 & signal-regulatory protein $\delta$ \\
\hline NEDD9 & 0.499 & NM_182966 & neural precursor cell expressed, developmentally down-regulated 9 \\
\hline TLR3 & $0.500^{\#}$ & NM_003265 & toll-like receptor 3 \\
\hline \multicolumn{4}{|l|}{ Group E } \\
\hline RAPSN & 0.354 & NM_005055 & receptor-associated protein of the synapse, $43 \mathrm{kDa}$ \\
\hline GRAP & 0.363 & NM_006613 & GRB2-related adaptor protein \\
\hline CD48 & 0.410 & NM_001778 & CD48 molecule \\
\hline LOC642966 & 0.428 & XM_926351 & similar to olfactory receptor 139 \\
\hline SALL1 & 0.437 & NM_002968 & sal-like 1 (Drosophila) \\
\hline
\end{tabular}


Table 7. Cont.

\begin{tabular}{|c|c|c|c|}
\hline Gene & Ratio * & Accession number & Description \\
\hline \multicolumn{4}{|l|}{ Group E } \\
\hline GLIS1 & 0.438 & NM_147193 & GLIS family zinc finger 1 \\
\hline FOLR1 & 0.471 & NM_016725 & folate receptor 1 (adult) \\
\hline NRG4 & 0.482 & NM_138573 & neuregulin 4 \\
\hline \multicolumn{4}{|l|}{ Group F } \\
\hline TACR1 & 0.408 & NM_015727 & tachykinin receptor 1 \\
\hline NHLH1 & 0.414 & NM_005598 & nescient helix loop helix 1 \\
\hline NF2 & 0.420 & NM_181825 & neurofibromin 2 (bilateral acoustic neuroma) \\
\hline LOC440607 & 0.427 & NM_001004340 & $\mathrm{Fc}-\gamma$ receptor I B2 \\
\hline MAF & 0.443 & NM_001031804 & v-maf musculoaponeurotic fibrosarcoma oncogene homolog (avian) \\
\hline ZNF160 & 0.449 & NM_033288 & zinc finger protein 160 \\
\hline DUSP2 & 0.454 & NM_004418 & dual specificity phosphatase 2 \\
\hline SOCS1 & 0.456 & NM_003745 & suppressor of cytokine signaling 1 \\
\hline CHRNA3 & 0.471 & NM_000743 & cholinergic receptor, nicotinic, $\alpha 3$ \\
\hline CRLF2 & 0.481 & NM_022148 & cytokine receptor-like factor 2 \\
\hline MRAP & 0.487 & NM_178817 & melanocortin 2 receptor accessory protein \\
\hline RPIP8 & 0.491 & NM_006695 & $\mathrm{RaP} 2$ interacting protein 8 \\
\hline \multicolumn{4}{|l|}{ Group G } \\
\hline CLEC4G & 0.198 & NM_198492 & C-type lectin superfamily 4 , member $G$ \\
\hline FSTL4 & 0.246 & NM_015082 & follistatin-like 4 \\
\hline RAB6C & 0.282 & NM_032144 & RAB6C, member RAS oncogene family \\
\hline CSF3 & 0.295 & NM_172220 & colony stimulating factor 3 (granulocyte) \\
\hline OR2T34 & 0.301 & NM_001001821 & olfactory receptor, family 2 , subfamily $\mathrm{T}$, member 34 \\
\hline RRP22 & 0.304 & NM_001007279 & RAS-related on chromosome 22 \\
\hline UTF1 & 0.305 & NM_003577 & undifferentiated embryonic cell transcription factor 1 \\
\hline CHRND & 0.306 & NM_000751 & cholinergic receptor, nicotinic, $\delta$ \\
\hline GPR6 & 0.316 & NM_005284 & G protein-coupled receptor 6 \\
\hline ANGPTL6 & 0.324 & NM_031917 & angiopoietin-like 6 \\
\hline OR2M7 & 0.346 & NM_001004691 & olfactory receptor, family 2 , subfamily $\mathrm{M}$, member 7 \\
\hline OR10P1 & 0.356 & NM_206899 & olfactory receptor, family 10 , subfamily $\mathrm{P}$, member 1 \\
\hline FOXD3 & 0.364 & NM_012183 & forkhead box D3 \\
\hline ZAP70 & 0.377 & NM_207519 & $\zeta$-chain (TCR) associated protein kinase $70 \mathrm{kDa}$ \\
\hline PTGER3 & 0.392 & NM_000957 & prostaglandin E receptor 3 (subtype EP3) \\
\hline $\mathrm{CDX} 4$ & 0.395 & NM_005193 & caudal type homeobox transcription factor 4 \\
\hline TBX21 & 0.405 & NM_013351 & T-box 21 \\
\hline TAS2R13 & 0.408 & NM_023920 & taste receptor, type 2 , member 13 \\
\hline IL17RE & 0.414 & NM_153482 & interleukin 17 receptor $\mathrm{E}$ \\
\hline PRDM9 & 0.415 & NM_020227 & PR domain containing 9 \\
\hline CXCL12 & 0.422 & NM_199168 & chemokine (C-X-C motif) ligand 12 (stromal cell-derived factor 1$)$ \\
\hline LILRA4 & 0.430 & NM_012276 & $\begin{array}{l}\text { leukocyte immunoglobulin-like receptor, subfamily A (with TM domain), } \\
\text { member } 4\end{array}$ \\
\hline LOC642506 & 0.433 & XM_926003 & similar to double homeobox $4 \mathrm{c}$ \\
\hline NEUROD6 & 0.435 & NM_022728 & neurogenic differentiation 6 \\
\hline KLF14 & 0.438 & NM_138693 & Kruppel-like factor 14 \\
\hline TFAP2E & 0.439 & NM_178548 & transcription factor AP-2 $\varepsilon$ (activating enhancer binding protein $2 \varepsilon$ ) \\
\hline
\end{tabular}


Table 7. Cont.

\begin{tabular}{|c|c|c|c|}
\hline Gene & Ratio * & Accession number & Description \\
\hline \multicolumn{4}{|l|}{ Group G } \\
\hline CCL1 & 0.439 & NM_002981 & chemokine (C-C motif) ligand 1 \\
\hline VAV3 & 0.439 & NM_006113 & vav 3 oncogene \\
\hline IRS3L & 0.444 & XM_498229 & insulin receptor substrate 3 -like \\
\hline GPR81 & 0.445 & NM_032554 & G protein-coupled receptor 81 \\
\hline GPR32 & 0.445 & NM_001506 & G protein-coupled receptor 32 \\
\hline GDF7 & 0.446 & NM_182828 & growth differentiation factor 7 \\
\hline WDR42C & 0.447 & XM_293354 & WD repeat domain $42 \mathrm{C}$ \\
\hline LOC619207 & 0.454 & XM_927516 & scavenger receptor protein family member \\
\hline FOLR1 & 0.457 & NM_016724 & folate receptor 1 (adult) \\
\hline ADRA1D & 0.457 & NM_000678 & adrenergic, $\alpha-1 D$-, receptor \\
\hline IL12RB2 & 0.459 & NM_001559 & interleukin 12 receptor, $\beta 2$ \\
\hline GRIN1 & 0.460 & NM_007327 & glutamate receptor, ionotropic, $N$-methyl D-aspartate 1 \\
\hline $\mathrm{SHC} 2$ & 0.461 & XM_375550 & SHC (Src homology 2 domain containing) transforming protein 2 \\
\hline RAXL1 & 0.464 & NM_032753 & retina and anterior neural fold homeobox like 1 \\
\hline CAMK2B & 0.472 & NM_172084 & calcium/calmodulin-dependent protein kinase (CaM kinase) II $\beta$ \\
\hline CCL15 & 0.473 & NM_004167 & chemokine (C-C motif) ligand 15 \\
\hline FSHR & 0.474 & NM_000145 & follicle stimulating hormone receptor \\
\hline WDR40B & 0.478 & NM_178470 & WD repeat domain $40 \mathrm{~B}$ \\
\hline MAFB & 0.482 & NM_005461 & v-maf musculoaponeurotic fibrosarcoma oncogene homolog B (avian) \\
\hline TPRX1 & 0.484 & NM_198479 & tetra-peptide repeat homeobox 1 \\
\hline FLT1 & 0.487 & NM_002019 & $\begin{array}{l}\text { fms-related tyrosine kinase } 1 \text { (vascular endothelial growth factor/vascular } \\
\text { permeability factor receptor) }\end{array}$ \\
\hline OLIG2 & 0.488 & NM_005806 & oligodendrocyte lineage transcription factor 2 \\
\hline TBXA2R & 0.490 & NM_001060 & thromboxane $\mathrm{A} 2$ receptor \\
\hline SSTR5 & 0.490 & NM_001053 & somatostatin receptor 5 \\
\hline MYOG & 0.491 & NM_002479 & myogenin (myogenic factor 4) \\
\hline OR2AG1 & 0.492 & NM_001004489 & olfactory receptor, family 2 , subfamily AG, member 1 \\
\hline FOXD4L1 & 0.495 & NM_012184 & forkhead box D4-like 1 \\
\hline PSPN & 0.495 & NM_004158 & persephin \\
\hline PJCG6 & 0.496 & NM_001040066 & similar to olfactory receptor 873 \\
\hline TSHR & 0.499 & NM_001018036 & thyroid stimulating hormone receptor \\
\hline
\end{tabular}

* ratio of the expression in cells cultured at $\mathrm{pH} 6.7$ after 24,5 , and $2 \mathrm{~h}$ culture to those at $\mathrm{pH} 7.5$ in groups A to D, E to F, and G, respectively; ${ }^{\#} 0.499857$.

\subsection{The Gene Expressions in Various Cells}

To confirm whether or not the gene expression pattern observed in mesothelioma cells is specific to these cells, we selected six genes, IL-32, TNFRSF9, AREG, ERBB3, ATP6V0D2, and DMGDH whose expressions were observed to increase more than three-fold at acidic $\mathrm{pH}$ using a microarray, and examined their expressions in various cells. IL-32 has been reported to be a cytokine, but its function remains unclear. TNFRSF9, AREG, and ERBB3 have been reported to be a receptor, growth factor, and oncogene product, respectively. ATP6V0D2 is one subunit of ATPase which has a role in $\mathrm{pH}$ regulation. DMGDH is a mitochondrial matrix enzyme. 
One problem in the measurement of mRNA was determining which gene was available as a control gene. A housekeeping gene such as GAPDH has been used generally until now. The previous report from our group showed that the amount of $18 \mathrm{~S}$ rRNA was constant at both acidic and alkaline $\mathrm{pH}$ in human $\mathrm{T}$ cells [15]. The amount of $18 \mathrm{~S}$ rRNA in mesothelioma cells did not vary as $\mathrm{pH}$ changed (data not shown). Based on these data, 18S rRNA was used as a control RNA in this study. The amount of ribosomes per cell was approximately $4 \times 10^{6}[25]$. The copy number of mRNA per cell can be estimated using this number.

IL-32, AREG, ERBB3, ATP6V0D2, and DMGDH genes showed increased expression in TE-11 cells after $24 \mathrm{~h}$ culture at acidic $\mathrm{pH}$ (Figure 1). These data were in agreement with the DNA array data. In contrast, the expression of TNFRSF9 did not increase under acidic $\mathrm{pH}$ in TE-11 (Figure 1).

The expression of IL-32 was increased at acidic pH in HT-29, HepG2, and BxPC3. HT-29 cells showed increased expressions of ERBB3, ATP6V0D2, and DMGDH at acidic pH, but the expressions of AREG and TNFRSF9 decreased. The expression of ATP6V0D2 was decreased by acidosis in BxPC3. The expressions of AREG, ERBB3, and ATP6V0D2 were not affected by $\mathrm{pH}$ in HepG2. These results suggested that genes whose expression is stimulated at acidic $\mathrm{pH}$ are different in different cells.

\section{Discussion}

The effect of acidosis on gene expression has been generally studied in medium without FBS until now. Cells are unable to proliferate under these conditions. In the present study, we used medium containing FBS which supported cell proliferation. We used medium without the addition of bicarbonate, because the medium $\mathrm{pH}$ was changed after the medium had been put into a $\mathrm{CO}_{2}$ incubator and the measurement of the exact $\mathrm{pH}$ value in the $\mathrm{CO}_{2}$ incubator was difficult. When the $\mathrm{CO}_{2}$ incubator is not used, the addition of bicarbonate is not necessary for cell proliferation. Bicarbonate is produced via metabolic processes, such as glycolysis and the citric acid cycle under aerobic conditions, and the production is enough for cell proliferation. In fact, all cell lines we used proliferated in medium without the addition of bicarbonate, and the proliferation rate was the same as that in medium with the addition of bicarbonate. The number of mesothelioma cells increased twofold during 2 days of incubation at $\mathrm{pH}$ 6.7 under our experimental conditions, but no proliferation was observed at $\mathrm{pH} 6.5$ or less. We therefore used pH 6.7 medium under acidic conditions in this study.

Some diseased areas are acidified, but the acidification is less than $1 \mathrm{pH}$ unit in many cases. Such a small change in $\mathrm{pH}$ has been thought to have little effect on mammalian cell functions until now. Our present data, however, clearly showed that acidification affects gene expression even if the $\mathrm{pH}$ change is small. Approximately 24,000 genes, about two-thirds of the mammalian genes, were analyzed in the present study, and 693 genes were up-regulated and 856 genes were down-regulated more than twofold at acidic $\mathrm{pH}$ in mesothelioma cells (Tables 3 and 6).

The expressions of 260 genes increased more than twofold in cells cultured at pH 6.7 for $2 \mathrm{~h}$ compared with $\mathrm{pH}$ 7.5. The expressions of 223 among the 260 genes decreased again after $24 \mathrm{~h}$ (Table 3 ). The physiological significance of the expression for a short time remains unclear. It is probably not due to the fluctuation of internal $\mathrm{pH}$ because the internal $\mathrm{pH}$ was decreased within $1 \mathrm{~h}$ after the acidic shift and then maintained at a constant level (data not shown). It has been generally accepted that the activation of the signal proteins increases rapidly after the stimulation and then decreases. It could be 
suggested that the expression levels of some genes for signal proteins decrease after the initial stimulation, although no direct evidence has yet been reported.

Our group found that the decrease in external $\mathrm{pH}$ below 7 changes the signal pathways, at least in part [11,12,15], and we identified a gene product that was essential for proliferation at acidic $\mathrm{pH}$ [13]. The present data showed that 84 genes for signaling were expressed more strongly after $24 \mathrm{~h}$ culture at acidic $\mathrm{pH}$. The functions of the 78 genes whose expressions were up-regulated at acidic $\mathrm{pH}$ are unknown. It might be possible that some of these unidentified genes encode proteins for cellular signaling.

Since translational activities are different in different genes, the mRNA level is not proportional to the enzyme level. Therefore, all protein levels encoded by genes whose expression is affected by $\mathrm{pH}$ may be required for clarifying the signal pathways working at acidic $\mathrm{pH}$. Furthermore, there are some genes whose expression is constitutive, but function is preferential at acidic $\mathrm{pH}$. Lao et al. found CTIB to be essential for growth at acidic $\mathrm{pH}$, but its expression was not affected by $\mathrm{pH}$ in the range from 6 to $8[13,14,27]$. p38 and ERK were activated strongly at acidic $\mathrm{pH}[12,15]$, but our present results showed no significant stimulation of their expression by acidosis. Identification of such proteins will be essential for improving our understanding of signal pathways operating under acidic diseased loci, and our present data could be useful for these studies as a database at the transcriptional level.

We found that different cytokines are expressed under different $\mathrm{pH}$ conditions (Tables 4 and 7). Especially IL-32 was found to express at a higher level at acidic $\mathrm{pH}$ in various cells. IL-32 was first identified in natural killer (NK) cells and IL-2 activated T cells [28], and was designated NK4. Since recombinant NK4 induced TNF- $\alpha$ production in human macrophages, it was assumed to have interleukin-like activity and hence was designated IL-32 [29]. Subsequent studies suggested that IL-32 is linked with pathological inflammation which often causes an acidic environment. Elevated IL-32 concentrations in synovial fluids and synovial tissues were demonstrated in rheumatoid arthritis but not in osteoarthritis patients [30,31]. Up-regulated IL-32 expression was also observed in the pancreatic ducts of chronic pancreatitis patients [32]. Taken together with our present data, IL-32 may be a factor that works under acidic conditions, but is not a cytokine specific to immune functions. IL-8, IL-15, and IL-16 were also up-regulated at acidic $\mathrm{pH}$, and these interleukins may work in acidic diseased areas.

Our present data suggest that different signal pathways operate under different $\mathrm{pH}$ conditions. Why do mammalian cells have this multiplicity of signaling systems? The underlying mechanism is still unclear. Cytosolic $\mathrm{pH}$ changed with the change in extracellular $\mathrm{pH}$, and the change in internal $\mathrm{pH}$ may affect protein activity because all proteins have $\mathrm{pH}$-dependent activity. One possible explanation is that an enzyme having maximum activity at acidic $\mathrm{pH}$ works under acidic $\mathrm{pH}$ instead of the enzyme having maximum activity at alkaline $\mathrm{pH}$. E. coli has multiple transport systems for sodium and potassium ions, and these systems work under different $\mathrm{pH}$ conditions $[9,10]$. Glycolysis was reported to increase in several tumors [1-3]. Only phosphoglycerate mutase 2 (muscle) was increased 2.03-fold at acidic $\mathrm{pH}$ (supplementary table), suggesting that other enzymes still work under acidic conditions without the elevation of transcription. Phosphoglycerate mutase 2 was reported to be a muscle-specific enzyme [33]. Since the muscles are often acidified, it can be argued that this enzyme works at acidic $\mathrm{pH}$ and the other isozyme does at alkaline $\mathrm{pH}$.

The expressions of many receptor genes were affected by the $\mathrm{pH}$ change (Tables 4 and 7). Since receptors in the cytoplasmic membranes generally have a domain located outside the cells, the activity may be more sensitive to external acidosis compared with the cytosolic enzymes, and the gene 
expression of many receptors having an optimum activity at acidic $\mathrm{pH}$ may be stimulated by acidosis to compensate for the functional decline of receptors having an optimum activity at alkaline $\mathrm{pH}$.

We used mesothelioma cells in the present study. Since the gene expression patterns were shown to be different in different cells, our present data may be applicable only to responses of mesothelioma cells. Analysis of the gene expressions in various cells, including non-tumor cells and normal tissues under acidic conditions will be essential for clarifying cell functions in acidic diseased areas.

\section{Conclusions}

Some diseased areas, such as cancer nests, inflammatory loci, and infarction areas, are acidified, but the acidification is less than $1 \mathrm{pH}$ unit in many cases. Our present data clearly showed that acidification affects gene expression even if the $\mathrm{pH}$ change is small. Approximately 24,000 genes, about two-thirds of the mammalian genes, were analyzed using mesothelioma cells. The expressions of 693 genes were up-regulated more than twofold at acidic $\mathrm{pH}$, and genes encoding proteins for signal pathways numbered 165 among the 693 genes. The expressions of 856 genes were down-regulated more than twofold at acidic $\mathrm{pH}$, and 194 among the 856 genes encoded proteins for signal pathways.

\section{Acknowledgements}

We would like to express our thanks to K. Chiba (Graduate School of Pharmaceutical Sciences, Chiba University) for his gift of HepG2. This work was supported by Special Funds for Education and Research (Development of SPECT Probes for Pharmaceutical Innovation) from the Ministry of Education, Culture, Sports, Science, and Technology of Japan.

\section{References}

1. Vaupel, P.; Kallinowski, F.; Okunieff, P. Blood flow, oxygen and nutrient supply, and metabolic microenvironment of human tumors: A review. Cancer Res. 1989, 49, 6449-6465.

2. Helmlinger, G.; Yuan, F.; Dellian, M.; Jain, R.K. Interstitial $\mathrm{pH}$ and $\mathrm{pO}_{2}$ gradients in solid tumors in vivo: high-resolution measurements reveal a lack of correlation. Nat. Med. 1997, 3, 177-182.

3. Warburg, O. On the origin of cancer cells. Science 1956, 123, 309-314.

4. Simmen, H.P.; Blaser, J. Analysis of $\mathrm{pH}$ and $\mathrm{pO}_{2}$ in abscesses, peritoneal fluid, and drainage fluid in the presence or absence of bacterial infection during and after abdominal surgery. Am. J. Surg. 1993, 166, 24-27.

5. Goldie, I.; Nachemson, A. Synovial pH in rheumatoid knee-joints. I. The effect of synovectomy. Acta Orthop. Scand. 1969, 40, 634-641.

6. Ward, T.T.; Steigbigel, R.T. Acidosis of synovial fluid correlates with synovial fluid leukocytosis. Am. J. Med. 1978, 64, 933-936.

7. Geborek, P.; Saxne, T.; Pettersson, H.; Wollheim, F.A. Synovial fluid acidosis correlates with radiological joint destruction in rheumatoid arthritis knee joints. J. Rheumatol. 1989, 16, 468-472.

8. Andersson, S.E.; Lexmüller, K.; Johansson, A.; Ekström, G.M. Tissue and intracellular pH in normal periarticular soft tissue and during different phases of antigen induced arthritis in the rat. J. Rheumatol. 1999, 26, 2018-2024. 
9. Ohyama, T.; Igarashi, K.; Kobayashi, H. Physiological role of the chaA gene in sodium and calcium circulations at a high pH in Escherichia coli. J. Bacteriol. 1994, 176, 4311-4315.

10. Trchounian, A.; Kobayashi, H. Kup is the major $\mathrm{K}^{+}$uptake system in Escherichia coli upon hyper-osmotic stress at a low pH. FEBS Lett. 1999, 447, 144-148.

11. Fukamachi, T.; Saito, H.; Kakegawa, T.; Kobayashi, H. Different proteins are phosphorylated under acidic environments in Jurkat cells. Immunol. Lett. 2002, 82, 155-158.

12. Hirata, S.; Fukamachi, T.; Sakano, H.; Tarora, A.; Saito, H.; Kobayashi, H. Extracellular acidic environments induce phosphorylation of ZAP-70 in Jurkat T cells. Immunol. Lett. 2008, 115, 105-109.

13. Lao, Q.; Fukamachi, T.; Saito, H.; Kuge, O.; Nishijima, M.; Kobayashi, H. Requirement of an $\mathrm{I} \kappa \mathrm{B}-\beta \mathrm{COOH}$ terminal region protein for acidic-adaptation in $\mathrm{CHO}$ cells. J. Cell Physiol. 2006, 207, 238-243.

14. Fukamachi, T.; Lao, Q.; Okamura, S.; Saito, H.; Kobayashi, H. CTIB ( $C$-Terminus protein of IкB- $\beta$ ): a novel factor required for acidic adaptation. Adv. Exp. Med. Biol. 2006, 584, 219-228.

15. Wang, X.; Hatatani, K.; Sun, Y.; Fukamachi, T.; Saito, H.; Kobayashi, H. TCR signaling via ZAP-70 induced by CD3 stimulation is more active under acidic conditions. J. Cell Sci. Ther. 2012, S16, 1.

16. Souza, R.F.; Shewmake, K.; Pearson, S.; Sarosi, G.A., Jr.; Feagins, L.A.; Ramirez, R.D.; Terada, L.S.; Spechler, S.J. Acid increases proliferation via ERK and p38 MAPK-mediated increases in cyclooxygenase-2 in Barrett's adenocarcinoma cells. Am. J. Physiol. Gastrointest. Liver Physiol. 2004, 287, G743-G748.

17. Kato, Y.; Lambert, C.A.; Colige, A.C.; Mineur, P.; Noël, A.; Frankenne, F.; Foidart, J.M.; Baba, M.; Hata, R.; Miyazaki, K.; et al. Acidic extracellular pH induces matrix metalloproteinase-9 expression in mouse metastatic melanoma cells through the phospholipase D-mitogen-activated protein kinase signaling. J. Biol. Chem. 2005, 280, 10938-10944.

18. Ihnatko, R.; Kubes, M.; Takacova, M.; Sedlakova, O.; Sedlak, J.; Pastorek, J.; Kopacek, J.; Pastorekova, S. Extracellular acidosis elevates carbonic anhydrase IX in human glioblastoma cells via transcriptional modulation that does not depend on hypoxia. Int. J. Oncol. 2006, 29, $1025-1033$.

19. Xu, L.; Fukumura, D.; Jain, R.K. Acidic extracellular $\mathrm{pH}$ induces vascular endothelial growth factor (VEGF) in human glioblastoma cells via ERK1/2 MAPK signaling pathway: Mechanism of low pH-induced VEGF. J. Biol. Chem. 2002, 277, 11368-11374.

20. Elias, A.P.; Dias, S. Microenvironment changes (in $\mathrm{pH}$ ) affect VEGF alternative splicing. Cancer Microenviron. 2008, 1, 131-139.

21. Hjelmeland, A.B.; Wu, Q.; Heddleston, J.M.; Choudhary, G.S.; MacSwords, J.; Lathia, J.D.; McLendon, R.; Lindner, D.; Sloan, A.; Rich, J.N. Acidic stress promotes a glioma stem cell phenotype. Cell Death Differ. 2010, 18, 829-840.

22. Tang, X.; Lucas, J.E.; Chen, J.L.; LaMonte, G.; Wu, J.; Wang, M.C.; Koumenis, C.; Chi, J.T. Functional interaction between responses to lactic acidosis and hypoxia regulates genomic transcriptional outputs. Cancer Res. 2012, 72, 491-502.

23. Irizarry, R.A.; Bolstad, B.M.; Collin, F.; Cope, L.M.; Hobbs, B.; Speed, T.P. Summaries of Affymetrix GeneChip probe level data. Nucleic Acids Res. 2003, 31, e15. 
24. Irizarry, R.A.; Hobbs, B.; Collin, F.; Beazer-Barclay, Y.D.; Antonellis, K.J.; Scherf, U.; Speed, T.P. Exploration, normalization, and summaries of high density oligonucleotide array probe level data. Biostatistics 2003, 4, 249-264.

25. Darnel, J.; Lodish, H.; Baltimore, D. Molecular Cell Biology; Scientific American Books Inc.: New York, NY, USA, 1986.

26. Connor, K.M.; Hempel, N.; Nelson, K.K.; Dabiri, G.; Gamarra, A.; Belarmino, J.; van de Water, L.; Mian, B.M.; Melendez, J.A. Manganese superoxide dismutase enhances the invasive and migratory activity of tumor cells. Cancer Res. 2007, 67, 10260-10267.

27. Lao, Q.; Kuge, O.; Fukamachi, T.; Kakegawa, T.; Saito, H.; Nishijima, M.; Kobayashi, H. An $\mathrm{I} \kappa \mathrm{B}-\beta \mathrm{COOH}$ terminal region protein is essential for the proliferation of $\mathrm{CHO}$ cells under acidic stress. J. Cell Physiol. 2005, 203, 186-192.

28. Dahl, C.A.; Schall, R.P.; He, H.L.; Cairns, J.S. Identification of a novel gene expressed in activated natural killer cells and T cells. J. Immunol. 1992, 148, 597-603.

29. Kim, S.H.; Han, S.Y.; Azam, T.; Yoon, D.Y.; Dinarello, C.A. Interleukin-32: A cytokine and inducer of TNFa. Immunity 2005, 22, 131-142.

30. Mun, S.H.; Kim, J.W.; Nah, S.S.; Ko, N.Y.; Lee, J.H.; Kim, J.D.; Kim, D.K.; Kim, H.S.; Choi, J.D.; Kim, S.H.; et al. Tumor necrosis factor $\alpha$-induced interleukin-32 is positively regulated via the Syk/protein kinase C $\delta / J N K$ pathway in rheumatoid synovial fibroblasts. Arthritis Rheum. 2009, 60, 678-685.

31. Joosten, L.A.; Netea, M.G.; Kim, S.H. IL-32, a proinflammatory cytokine in rheumatoid arthritis. Proc. Natl. Acad. Sci. USA 2006, 103, 3298-3303.

32. Nishida, A.; Andoh, A.; Inatomi, O.; Fujiyama, Y. Interleukin-32 expression in the pancreas. J. Biol. Chem. 2009, 284, 17868-17876.

33. Castella-Escola, J.; Ojcius, D.M.; LeBoulch, P.; Joulin, V.; Blouquit, Y.; Garel, M.C.; Valentin, C.; Rosa, R.; Climent-Romeo, F.; Cohen-Solal, M. Isolation and characterization of the gene encoding the muscle-specific isozyme of human phosphoglycerate mutase. Gene 1990, 91, $225-232$.

(C) 2013 by the authors; licensee MDPI, Basel, Switzerland. This article is an open access article distributed under the terms and conditions of the Creative Commons Attribution license (http://creativecommons.org/licenses/by/3.0/). 